\title{
Neo sufism and the concept of seven dignities of Muhammad Nafis al-Banjari
}

\author{
Miftah Arifin ${ }^{1 *}$ \\ ${ }^{1}$ Institut Agama Islam Negeri Jember, Indonesia \\ *Corresponding author: miftaharifin@iain-jember.ac.id
}

\section{KEYWORDS}

Muhammad Nafis al-Banjari seven dignities

durr al-Nafis.

\begin{abstract}
This study aims to describe how Muhammad Nafis al-Banjari's position in transmitting the doctrine of wahdat al-wujud in Indonesia. The research used a descriptive form with a qualitative approach and historical method. This study through four stages, namely heuristics, source criticism, interpretation and presentation. Nafis al-Banjari has played a vital role in transmitting wahdat al-wujud thought in Indonesia. Firstly, the thought of wahdat al-wujud tends to be difficult to be understood, but the next time, it can be explained more easily through the concept of the seven dignities. Nafis al-Banjari then explained the concept of The Book of Tuhfah al-Mursalah, written by al-Burhanpuri in his primary book, namely Durr al-Nafis.
\end{abstract}

(c) The Author(s) 2021

\section{INTRODUCTION}

The Kalimantan region is known as one of the areas that received Islam later compared to other areas in Indonesia. According to Hikayat Banjar, Islam reached the momentum in Kalimantan when Demak troops of Java arrived in Banjarmasin to help Prince Samudra. After his victory, Prince Samudera converted to Islam and changed to be Sultan Surian Syah as the first sultan. For a long time, Islam in Kalimantan only gained a few followers and was always a minority because Islam was only followed by the Malays, who were immigrants. Meanwhile, Islam was only able to enter slowly into the Dayak tribe, the original ethnic groups of Kalimantan.

There was no adequate information about how spreads Islam di Kalimantan was under the control of the sultan. There were no clear and systematic efforts to promote Islam in South Kalimantan. However, they used Arabic script to correspond with other rulers in the archipelago. Until then, the spread of Islam reached its momentum with establishing several religious institutions in South Kalimantan at the initiative of Muhammad Arsyad al-Banjari (1710 1812 AD). Arsyad al-Banjari was involved in a polemic with adherents of the wahdat al-wujūd doctrine known as Abd al-Hamid in his area. In the next turn, the sultan decided to sentence Haji Abd al-Hamid to death.

These conflicts and tensions between Sufis and nonSufis happened continuously. However, since the arrival of scholars such as Muhammad Arsyad al-Banjari and Muhammad Nafis al-Banjari, these conflicts could be managed and resolved. Sufism that is considered heretical can be returned in a form that is in harmony with the shari'ah, especially that carried out by Muhammad Nafis al-Banjari. Since then, tensions and conflicts have decreased, especially in the area of Kalimantan.
He wrote a very famous book entitled Durr al-Nafis. This book explains the doctrines of Sufism, especially about stages in Sufism in e new model and explains the doctrine of the seven dignities. This book became public reading among the people of South Kalimantan in the middle of the twentieth century, although there was controversy over this book. Some scholars state that this book is not following Sunni Sufism, but some others received it. Muhammad Nafis's Sufism teaches not only Sunni Sufism and not only philosophical tasawut. But it bridged the gap between the two types of Sufism, and then he combined the two. Through this book, the Sufi teachings can be well received in this area. The development of Sufism in South Kalimantan reached the golden age in Muhammad al-Nafis Banjari period (Ahmadi, 1996).

This theme becomes important to review that the central theme of neo-Sufism in the 17th century $\mathrm{AD}$ was the harmony between the shari'a aspects (legal aspects) and Islamic spirituality (Sufism). In almost the entire Islamic world, including in Indonesia, there is tension between $\mathrm{Su}^{-}$ fis and non-Sufis. After what happened in Aceh in the 17th century AD. and spread to other areas, later scholars such as Abdurrauf al-Singkili and Abd Samad al-Palimbani tried to reconcile Sufism and Shari'ah as was done by previous scholars as has been done by Imam al-Ghazali. If in Sumatra there are scholars such as al-Sinkili and al-Palimbani, then in Kalimantan, the scholar who does the same thing well is Muhammad Nafis al-Banjari. This shows that the renewal of Sufism was carried out by Indonesian scholars continuously and is still ongoing today (Howell, 2012).

\section{METHOD}

The research used a descriptive form with a qualitative approach and historical method. The historical method is carried out by comparing several historical works and reliable 
sources based on the historical method. Intertextual studies are needed to reveal ideas or polemics that occurred because the texts and writings produced by Indonesian figures cannot be separated from the situations and conditions when the text was written. The written text could be in response to any questions around in society or written at the ruler's request. Therefore the ideas and thoughts of people written at that time in any form such as manuscripts or other people's ideas became very important. In addition, the writings produced by scholars about ideas and figures become an important material to enrich this study.

This study through four stages, namely heuristics, source criticism, interpretation and presentation. Heuristics is an activity to collect traces or signs of the past. After that, a critical review is carried out to investigate whether the traces are true based on historical methods. From the collected data, interpretation is carried out to determine the interconnected meanings of the facts obtained. Meanwhile, the final step is to convey a synthesis of the data obtained (Hegelian Analysis).

\section{RESULTS AND DISCUSSION}

\subsection{His Life and Works}

He was well known as a Sufi through his primary work entitled Darr al-Nafis fi Bayan al-Wahdat al-Af'al wa al-Asma' wa al-Shifat, which spread widely in Indonesia. He was born in Martapura in $1735 \mathrm{AD}$ in the Duke family, so Nafis alBanjari lived in the more recent period compared with Arsyad al-Banjari. After that, al-Nafis Banjari went to Mecca to study, but it is not found who his friends were in Haramayn. The actual year of birth of al-Nafis Banjari can not be determined with certainty. In 1735, it was generated from the calculations that in his book al-Durr al-Nafis stated that the book was completed in the year $1200 \mathrm{AH} / 1785$ if it is assumed he finished the book at the age of 50 years, the estimated year of birth is about $1735 \mathrm{AD}$.

In Makkah, al-Banjari wrote a book of mysticism in Malay entitled al-Darr al-Nafis fi Bayan wahdat al-Af'al wa al-Asma' wa al-sifat wa al-aat alTaqdis (the Beautiful Pearl of Explaining the Unity of Deed, Name, Nature, and the Purified Substance) completed in 1785 AD. In the book, it mentioned some refferences, among others; Syarh Dala'il al-Khairat of Muhammad Sulaiman al-Jazuli, Syarh al-Wird al-Syahrin of Abdullah bin Hijazi al Syarqawi alMisri, Jawahir wa al-Durar of Abd alWahhab al-Sya'rani, Futuhat al-Makkiyah dan Fushush al-Hikam of ibn Arabi, Insan al-Kamil of al-Jili, Ihya' Ulum al-Din by al-Ghazali, and so on.

The lists used as references could understand that Darr al-Nafis is not a regular Sufism book, but it combines the works of controversial people such as Ibn Arabi. Nafis alBanjari was fully aware of this; it is said that this book contains problems that are subtle and profound and secret, which could only be understood by those who have high knowledge (Al-Banjari, n.d.).

In addition to the book, it is not found another work of al-Nafis Banjari, but Abdullah still mentions another work of al-Nafis Banjari, which is Kanz al-Sa'adat fi Istilahat alSuffiyah (the Treasury of Happiness; the explanation of Sufi terms). This book has not been found so that it is a doubt about its existence.

In al-Durr al-Nafis, Nafis al-Banjari mentions many of his teachers in Haramayn, among them; al-sammani,
Muhammad al-Jawhari, Abdullah ibn al-Hijazi Syarqawi -a famous Sufi scholar in Mecca who was then on the charge of Sheikh of al-Islam and Sheikh of al-Azhar. Another teacher was Muhammad Siddiq bin Umar Khan and Abd al-Rahman ibn Abd al-Aziz al-Maghribi (Abdullah, 1980) This book also explains that in the field of jurisprudence, he follows the Shafi'i madhab. In theology, he follows the Ash'ari madhab, in the field of Sufism, he follows al-Junaid, and in the field of tareqat, he claimed to be a follower of Qadiriyah, Syattariyah, Naqsyabandiyah, Khalwatiyah, and Sammaniyah. (al-Banjari, n.d.)

\subsection{Neo Sufism of Muhammad Nafis al-Banjari}

Neo Sufism is generally defined as a movement characterized by refusing extravagant Sufism, not prioritizing Sufi eschatism and metaphysics, but prioritizing practice that strictly adheres to Shari'ah. A clear definition of the meaning and use of the term neo-Sufism was started by Fazlur Rahman. Neo Sufism is Sufism that has been renewed, especially stripped of its eschatism and metaphysical content, and replaced by orthodoxy theorems (Fazlurrahman, 1979) . This neosufism emphasizes and renews the moral factor and removes the excessive traits of deviant Sufism. Therefore, the concern of neo-Sufism is the socio-moral reconstruction of the Muslim community. This is different from the previous characteristics of Sufism which prioritized forms of individual piety compared to society. While (Trimingham, 1971) says, this is called the middle way, namely combining fiqh and Sufism.

The emergence of these movements has not only occurred in recent centuries but has begun in the classical era when there was a conflict between speculative ascetic Sufis who were seen as heterodox and shari'ah groups (especially ahl al-hadits). At that time, the spirit of the speculative Sufis was always viewed with suspicion. The traditions of these Sufis, who often separated themselves from the famous great scholars (faqih), were always suspected by these scholars. The excessive anger and suspicion of these legalists caused, for example, Shihab al-Dun Yahya al-Suhrawardi to become one of the victims (Shah, 1964).

The resistance by legalists to this Sufi practice took place vigorously and continuously, for example, the resistance of the Hanbali scholars to the behaviour of the Sufi schools of al-Muhasabi, Sari al-Saqati and their followers. The censure of Ibn al-Qayyim al-Jawziyah (d.597/1200) in his half work entitled Talbis Iblis to the Sufis by attacking their differences from shar'i law. Ibn Taymiyah (d.728/1328) attacked the behaviour of the Sufis by distributing many fatwas and writing pamphlets. Ibn Taymiya denounced Sufi practices in his ecstasy through music and dances and pilgrimages to tombs with treats. Everything is said to be something that is contrary to sharia(Trimingham, 1971).

However, there is no authentic evidence that the hadith experts are against all forms of Sufism because what they reject is actually ascetic and excessive Sufism that ignores shari'ah. The Hambali scholars who are known for their steadfastness in adhering to the hadith and their rejection of rational philosophy and speculative mysticism have apparently accepted Sufism. They accept Sufism on the condition that it is carried out in accordance with Shari'ah teachings. This case can be found in, for example, Ibn Taymiyah (d.728/1328) or Ibn al-Qayyim al-Jauziyah (d. 597/1200) (Rahman, 2000). From both, there is no evidence that they oppose Sufism blindly. They only oppose the ex- 
cessive practice of Sufism, ignore the shari'ah aspect and seem to only prioritize the essence aspect. These people do not denounce what is called Sufism, but what they consider to be illegality (Trimingham, 1971:151)

Neosufism that occurred in the archipelago at the end of the seventeenth century onwards was an idea conveyed by the Haramayn scholar and brought to the archipelago through his Javanese students. Scholars such as al-Kurani and al-Barzanji spawned neo-Sufism ideas through their students, such as 'Abd al-Rauf al-Sinkili to the archipelago in the 17th century AD. And in the 18th century, Abd alShamad al-Palimbani was the disciples of al-Sammani also did the same.

As stated by John (1975), that the polemic issues in Aceh had arrived in Mecca and were discussed by Haramayn scholars. Even al-Kurani wrote a treatise specifically dealing with Javanese problems later. Al-Sinkili, as one of the students of al-Kurani, took a more moderate path in dealing with the problems of the wahdat al-wujūd doctrine that existed in society. 'Abd al-Rauf al-Sinkili was a prolific writer in various aspects of both the inner sciences (Sufism) and the outer sciences (shari'ah) such as fiqh, hadith, and interpretation. Neo Sufism also penetrated into the Kalimantan region through Muhammad Arsyad al-Banjari, who was a friend of Abd al-Shamad al-Palimbani. In contrast to alPalimbani, who tried to reconcile the traditions of Islamic Sufism, Arsyad al-Banjari was more concerned with implementing the shari'ah aspect in Kalimantan.

The reconciliation of Sufism and sharia in Kalimantan was carried out by the next scholar, Muhammad Nafis alBanjari, who composed the book Durr al-Nāfis. In al-Durr al-Nafis, Nafis al-Banjari followed his senior scholars who were concerned over the renewal of Sufism; he always emphasized the absolute transcendence and the unity of God because he believed that no one is able to know the secret of God. Al-Banjari, when he explained about monotheism, he said that no one could know the nature of the substance of God, even the apostles and angels. (Al-Banjari, n.d.).

In addition to clarifying the philosophical Sufism that explains God and Nature, al-Banjari also explains the procedures that should be followed by salik (who follows the Sufi path) to reach God's Blessing (ridlo). The descriptions of al-Nafis Banjari reminds us of al-Ghazali's concept in Ihya' Ulum al-Din about the book of ugliness (muhlikat) and goodness (munjiyat). The first, the follower (salik) must know all things that can cancel and thwart him compare with Ihya 'Ulm al-Din, especially the al-muhlikat part (devastating) - to reach God's Blessing (ridlo). For that, salik must maintain various immoral both inwardly and outwardly. After the follower successfully overcomes the problems that could derail him from getting closer to God, then he must do things that can deliver to the next levels (AlGhazali, 1990).

After al-Banjari explains the foundation of the Shariah in achieving mystical way in his book, the next discussion is around the wahdat al-wujud (unity of being) concept. In this case, al-Banjari adopts the ideas of earlier scholars on the subject of manifestation. It is said that no one who knows the essence of God, then there are no words that can describe Him except to understand the term is not and no. Durr al-Nafis describes:

"The beginning is Allaah form, and his substance is not a form (jisim), He is not an essence (Jauhar), He is not a substance (aradh), He is not united in (Ittihad), He is not come down (hulul), and he does not do jihad, and there is no for Him He is no finite, and He is no beginning, and He is different from all things." (Al-Banjari, nd.).

Al-Banjari's description of God's absolute substance shows like the Arabian school (madhab) in explaining God in the first stage (martabat ahadiyat) (la ta'ayun). God is a substance that is not known by anyone, but He wants to be known so that God can be known. He must show Himself through the manifestation (tajalli) process. (al-Banjari, nd)250 Like other scholars of Arabian school (madhab), alBanjari quotes a very popular hadith of prophet

"I am hidden treasury, and I miss to be known, so I create beings so that they know Me" (Al-Ghazali, 1990).

The manifestation of God (Tajalli al-Haqq) process in the conception of alBanjari adopted the concept of the dignity of seven by alBurhanpuri. The first dignity is martabat ahadiyat, which is the appearance of the whole nature and His names (asma), but both sank into God's substance. This dignity is the highest dignity. The second dignity is martabat wahdat. In this dignity, every nature and God's asma has appeared in general (ijmal), which is said to be the essence of the prophet Muhammad which is the essence of nature and essence of everything because according to al-Nafis Banjari, everything was created from the Nur Muhammad, then Muhammad is also called huwwiyat al-alam. The third dignity is martabat wahidiyat, which is the appearance of any nature and His names(asma) in particular (tafsili), from His all names (asma) and nature which is general (mujmal) on the previous dignity.

Nafis al-Banjari has been explained as follows, "The first of the tanzil dignities is martabat ahadiyah, then it produces all natures and names (asma), but both are embodied in the substance. Martabat Ahadiyah is the highest dignity that is martabat kunhi zat Allah Ta'ala.

The second of Martabat tanazzul is martabat Wahdah. It produces all natures and names (asma) generally (organization), that is the substance of our prophet Muhammad which is the origin of all the entities and the rest of his life. So it is our prophet Muhammad who is huwwiyat al-Alam, it means that the essence of nature and origin of all things (asyya') because that all things (asyya') were made of our prophet Muhammad nur.

The third of martabat tanzil is martabat wahidiyyah which produces all the nature and names (asma) by dividing the existing goods, and it becomes general (mujmal) on Wahdah and on this wahidiyyah produces this book, that is his sentence inna ana Allah which means that I am God. It starts because it receives khitab with kalam that is qadim on wahidiyyah because it is obtained khitab with it, which is alam sifat and asma' (the world of nature and names) (AlBanjari, nd.).

These three dignities include a'yan tsabitah (permanent entity) that still has been potential and not produced outwardly. Al-A'yun al-Khariji, which is the next level, starts with martabat alam arwah as the fourth dignity. Martabat alam arwah is the essence of all souls (spirits) that are not arranged. It is silent from all things arranged and widely spread; that is the essence of all outer soul. It is on all substance and illustration.

The fifth dignity is martabat alam mitsal that is something subtle and can not be divided. It means all things become smooth form, and it does not receive happiness. The sixth dignity is martabat alam ajsam that is everything rough and can be divided. It means that all things become 
more rugged; they receive happiness. The Seventh dignity is martabat alam insan; that is the dignity that collects all the previous six dignities (Al-Banjari, nd.).

Regarding the relationship between God and nature, alBanjari used waves, ocean, and froth terminologies. Everything essentially is water. As it is expressed by the following:

"Alam Mitsal by the Sufi (Arif Billah) because it also emphasizes the concept of not the substance, like a sea, wave and foam, and all of them is also water. Nothing is manifested only with water. When the outer is a move, from that, they become the waves and froth. When the place is vast, the water becomes sea, but nevertheless, it is water. Covering the form of water is ocean, waves and foam as if water does not move and the place is narrow, and undoubtedly there will never be sea, wave, and foam. Then it returns to water and sea and foam also go to be water, Such as manifestation of Allah, it covers His form in all of nature, there will never be an entity, and everything is mortal (fana) in the manifestation of God (Allah Ta'ala)." (Al-Banjari, nd.).

The expression of waves and sea reminds to the expression conveyed by Hamzah Fansuri in his work of Syarab alAsyiqin, and it also can be found in the book of al-Jili entitled Al-Insan al-Kamil about the expression of water with ice (Hadi, 1995).

As an illustration, a creature is similar to ice And you are the running water Ice actually it comes from water It is because it has decided to be such (Al-Jili, 1956)

Then al-Banjari asserts that human dignity potentially can achieve martabat insan kamil if he could get through the dignities as it already mentioned so that it units in beautiness (Jamal) and perfectness (Jalal) as reflected in the prophet Muhammad characters. Actually, every action is an act of God, and people do not have the slightest act at all, and all asma is asma God, all nature is the nature of God, and all things that are in creature are only His form. This is the highest monotheism in view of al-Nafis Banjari (AlBanjari, nd.).

In turn, Nafis al-Banjari was well known for spreading the teachings of Islam to the inland region. It made Nafis widely known as the nomad scholar. One of the results of the preaching reached Kalua (now included in the Tabalong territory), in the 19th century had been transformed into the centre of the spread of Islam in the northern part of South Kalimantan.
He had a very big role in spreading Islam in the region of the Banjar Sultanate. Until then, Nafis was given the honorary title of Maulana alAllamah al-Fakhamah al-Mursyid ila Tariq as-Salamah (The noble, highly knowledgeable, respected counsellor to the righteous path) (Asidiq, 2003).

\section{CONCLUSION}

Muhammad Nafis al-Banjari has a very important role in the transmission of neosufism and the reconciliation of wahdat al-wujud thoughts in Indonesia. At first, the idea of wahdat al-Manifestation tends to be difficult to understand, but the next, it can be explained more easily through the concept of the seven dignity. This concept was first introduced by al-Burhanpuri in his work entitled Tuhfah al-Mursalah (Alburhanpuri, 1965). This book of tuhfah inspired the scholars who came next to continue reconciling Sufism. One of them is Muhammad Nafis al-Banjari then explains the concept of Tuhfah in his main book is entitled Durr al-Nafis.

\section{REFERENCES}

Abdullah, H. (1980). Perkembangan Ilmu Tasawuf dan TokohTokohnya di Nusantara. Al-Ikhlas.

Ahmadi, I. (1996). Ajaran Tasawuf Syekh Muhammad Nafis al-Banjari. IAIN Jakarta.

Al-Banjari, Muhammad Nafis. (nd.) Al-Durr al-Nafis. alHaramain.

Al-burhanpuri. (1965). Tuhfat al-Mursalah ila ruh al-Nabi. The Australian National University.

Al-Ghazali, A. H. M. (1990). Ihyā Ulūm al-Drn. Dar al-Fikr.

Al-Jili. (1956). al-Insan al-Kamil. Syirkah Maktabah wa Mathba'ah Musthafa al-Bab al-Halaj.

Asidiq, Y. (2003). Muhammad Nafis al-Banjari: Sang Ulama Pengembara. Republika.

Fazlurrahman. (1979). Islam. Chicago University Press.

Hadi, A. (1995). Hamzah Fansuri, Risalah Tasawuf dan Puisinya. Mizan.

Howell, J. D. (2012). Sufism and Neo Sufism in Indonesia Today. Review of Indonesian and Malaysian Affairs, 46(2), $1-24$.

Shah, I. (1964). The Sufis. Anchor Books Doubleday \& Company Inc.

Trimingham, J. S. (1971). The Sufi Order in Islam. Oxford Univ. Press. 